\title{
Environmental characteristics of karst in China and their effect on engineering
}

\author{
Yaoru Lu $\cdot$ Qi Liu $\cdot$ Feng'e Zhang
}

Accepted: 4 March 2013/Published online: 30 March 2013

(C) The Author(s) 2013. This article is published with open access at Springerlink.com

\begin{abstract}
Due to the diverse geology and environmental conditions in China, karst development is characterized by great variety and regional regularities. At the same time, the engineering effect involved in the construction and development work undertaken in karst regions varies considerably. This article describes the regional characteristics of karst development in China, analysis of its karst hydrogeological conditions and the main geological engineering problems in karst area. Karst environmental conditions usually include both resource factors and hazard factors. For the exploitation of different resources in karst regions, it is very important to avoid geohazards such as karst collapses, landslides, and debris flows as well as causing karst water invasion. Otherwise, according to the local hazard conditions, treatment can be implemented for decreasing the natural hazard and reducing potential harm.
\end{abstract}

Keywords Karst development - Hydrogeological conditions $\cdot$ Geological engineering effect

Y. Lu $\cdot$ F. Zhang

Institute of Hydrogeology and Environmental Geology, China Academy of Geological Sciences, Shijiazhuang 050061, China

Y. Lu $(\bowtie) \cdot$ Q. Liu

Department of Geotechnical Engineering, Tongji University, Shanghai 200092, China

e-mail: yrlu@tongji.edu.cn

Y. Lu · Q. Liu

Joint Research Center of Urban Environment and Sustainable

Development, Ministry of Education, Shanghai 200092, China

\section{Introduction}

Due to the diverse geology and environmental conditions in China, karst development is characterized by great variety and regional regularities (Lu 2012). At the same time, the engineering effect involved in the construction and development work undertaken in karst regions varies considerably (Lu 1999). This article examines some of the problems.

\section{Regional characteristics of karst development in China}

Generally, karst development in China is greatly influenced by the major factors of geological structure and climate ( $\mathrm{Lu}$ 1999). In particular, karst has developed since the Yanshan and the Himalayas orogenies, both of which define the fundamental structure of China.

Continent-continent collision and associated thrusting between the Indian and the Eurasian plates has resulted in the rise of the Himalayan Mountains and the Qinghai-Tibet Plateau, both with altitudes over 3,000 m, composing the first geomorphological action in China. The rise of Yunnan-Guizhou Plateau (altitude 1,000-2,000 m) was the second. Meanwhile, in the eastern part of China, with the influence of the Pacific Plate, a chain of islands emerged, among which was Taiwan Island. Central mountains came into being, with the Qinling Mountains located in the middle of China providing a natural boundary between the north and south of the country (Lu et al. 1973).

This tectonism, with the subsequent effects of various climate conditions, resulted in the regional differences that are present today. On the basis of these differences, China can be divided into seven major regions and climate elements in terms of karst development (Figs. 1, 2) (Lu 1986, 2003). 


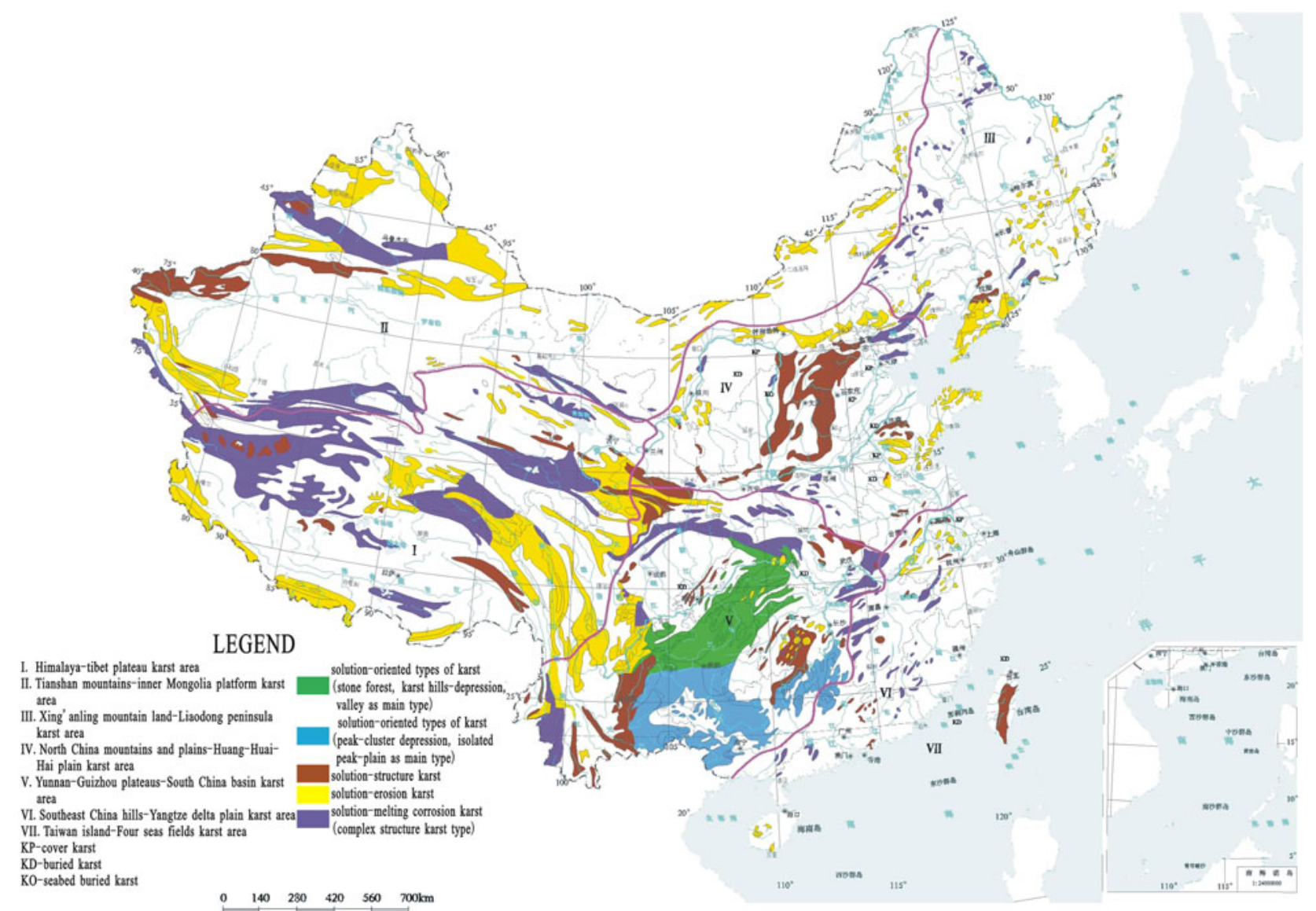

Fig. 1 Karst divisions in China and their main characteristics (Lu 2003)

Fig. 2 A comparison of the climate elements in the different divisions. a annual solar radiant heat; $\mathbf{b}$ annual sunshine duration; c annual average temperature; $\mathbf{d}$ annual temperature difference; $\mathbf{e}$ annual average rainfall; $\mathbf{f}$ annual average relative humidity; g annual surface runoff depth; h surface runoff coefficient; i elevation; $\mathbf{j}$ elevation difference. Karst hydrogeological region: I the Qinghai-Tibet Plateau; II Xinjiang and Inner Mongolia; III Northeast China; IV North China; $V$ the Yunnan-Guizhou Plateau-South China Basin; VI Southeast China; VII Taiwan Island and territorial waters
A

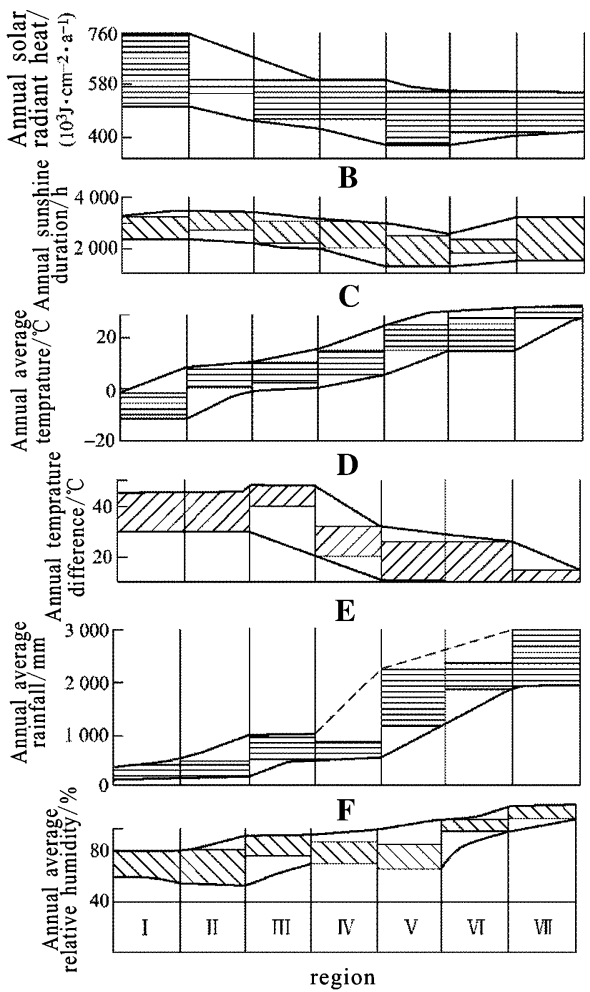

G

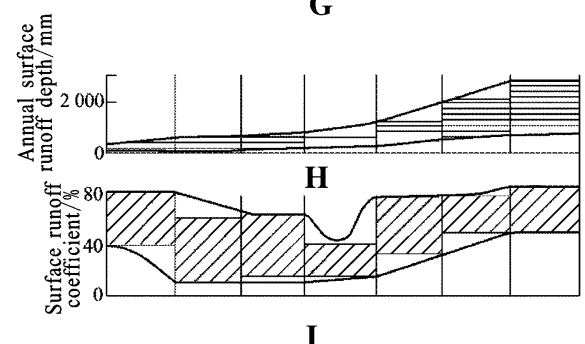

I
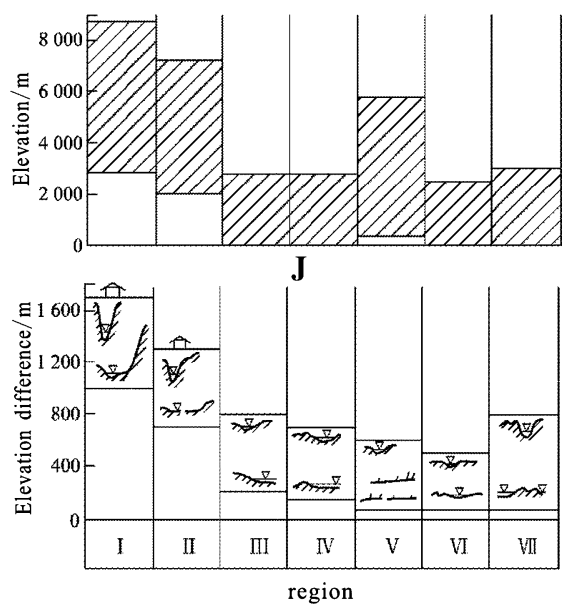
Table 1 Evaluation coefficient results of the basic environmental characteristics of the seven karst regions in China

\begin{tabular}{|c|c|c|c|c|c|c|c|}
\hline \multirow[t]{2}{*}{ Factor } & \multicolumn{7}{|l|}{ Regions } \\
\hline & $\begin{array}{l}\text { I. Tibetan } \\
\text { Plateau }\end{array}$ & $\begin{array}{l}\text { II. Xinjiang- } \\
\text { Inner } \\
\text { Mongolia }\end{array}$ & $\begin{array}{l}\text { III. } \\
\text { Northeast }\end{array}$ & $\begin{array}{l}\text { IV. } \\
\text { North }\end{array}$ & $\begin{array}{l}\text { V. Yunnan-Guizhou } \\
\text { plateaus-south } \\
\text { China basin }\end{array}$ & $\begin{array}{l}\text { VI. } \\
\text { Southeast }\end{array}$ & $\begin{array}{l}\text { VII. Taiwan } \\
\text { Island-Four } \\
\text { seas fields }\end{array}$ \\
\hline Solar radiation heat $\left(A_{1} \cdot X_{1}\right)$ & 15.0 & 13.5 & 12.5 & 12.5 & 11.0 & 12.0 & 12.0 \\
\hline Sunshine time $\left(A_{2} \cdot X_{2}\right)$ & 14.0 & 15.0 & 13.0 & 12.0 & 8.5 & 9.0 & 11.0 \\
\hline Average annual temperature $\left(A_{3} \cdot X_{3}\right)$ & 1 & 3 & 4 & 10 & 19 & 20 & 23 \\
\hline Annual temperature difference $\left(A_{4} \cdot X_{4}\right)$ & 6 & 6 & 6 & 7 & 8 & 8 & 10 \\
\hline Annual precipitation $\left(A_{5} \cdot X_{5}\right)$ & 2.3 & 4.0 & 7.0 & 6.0 & 10.0 & 21.5 & 25.0 \\
\hline Annual relative humidity $\left(A_{6} \cdot X_{6}\right)$ & 5 & 4 & 6 & 6 & 7 & 7 & 8 \\
\hline Surface runoff depth $\left(A_{7} \cdot X_{7}\right)$ & 0.1 & 0.05 & 0.1 & 0.1 & 8.5 & 13.5 & 18.0 \\
\hline Annual surface runoff $\left(A_{8} \cdot X_{8}\right)$ & 12 & 7 & 7 & 5 & 10 & 12 & 13 \\
\hline Height $\left(A_{9} \cdot X_{9}\right)$ & 6 & 6 & 8 & 8 & 8 & 10 & 9 \\
\hline Landform $\left(A_{10} \cdot X_{10}\right)$ & 8 & 12 & 16 & 16 & 18 & 20 & 12 \\
\hline Total evaluation coefficient $\left(C_{\mathrm{n}}^{\mathrm{R}}\right)$ & 69.35 & 70.55 & 78.6 & 81.6 & 108.0 & 132.5 & 151.0 \\
\hline
\end{tabular}

The various environmental factors affecting karst development in each of these regions may be quantified through the use of an evaluation coefficient:

$C_{\mathrm{n}}^{\mathrm{R}}=\sum_{i=1}^{n} A_{i}-X_{i}$

where $C_{\mathrm{n}}^{\mathrm{R}}$ evaluation coefficient; $A_{i}$ i factor; $X_{i}$ parameter of $i$; and $n$ number of evaluation factors in Table 1 (Lu 2003).

\section{Comparison of the karst hydrogeological conditions}

Karst landforms differ between each of the seven regions, and accordingly, so do their hydrogeological conditions. Because of space constraints, this study mainly compares region IV, karst in northern China, and region V, karst in southwest and central south China. Comparison of karst hydrogeological conditions in southern and northern China is made in Table 2.

Karst in region $\mathrm{V}$ covers seven provinces, municipalities, and autonomous regions: Yunnan, Guizhou, Sichuan, Chongqing, Guangxi, Hunan, and Hubei. The major karst rivers in these areas are listed in Table 3 (Lu 2007). Some eco-hydrological conditions as the main contents of karst water in South China and in North China have been evaluated in earlier studies (Lu 2007).

As the most well-known karst development area in southern China, this area largely features dissolution karst and tectonics-dissolution karst. Dissolution-erosion karst is also common there, since this area is located in middle and upper reaches of the Yangtze River and the Pearl River, and boasts $1,000-2,000 \mathrm{~mm} /$ year of rainfall.
Table 2 Comparison of karst hydrogeological conditions in southern and northern China

\begin{tabular}{|c|c|c|}
\hline & North China & South China \\
\hline Karst caves & Larger cave systems & $\begin{array}{l}\text { Many larger cave } \\
\text { systems }\end{array}$ \\
\hline Karst spring & $\begin{array}{l}\text { Larger karst spring } \\
\text { systems }\end{array}$ & $\begin{array}{l}\text { Developing many karst } \\
\text { spring systems }\end{array}$ \\
\hline $\begin{array}{l}\text { Maximum } \\
\text { discharges }\end{array}$ & $16 \mathrm{~m}^{3} / \mathrm{s}$ in karst spring & $\begin{array}{l}400 \mathrm{~m}^{3} / \mathrm{s} \text { in ground karst } \\
\text { ground river }\end{array}$ \\
\hline $\begin{array}{c}\text { Flowing } \\
\text { speed }\end{array}$ & $\begin{array}{l}\text { Commonly } 1 \mathrm{~m} / \text { day to } \\
\text { several ten } \mathrm{m} / \text { day }\end{array}$ & $\begin{array}{l}\text { Several ten } \mathrm{m} / \text { day to } \\
\text { several thousand } \\
\mathrm{m} / \text { day }\end{array}$ \\
\hline
\end{tabular}

Table 3 Main karst underground rivers in the 7 provinces, municipalities, and autonomous regions in region $\mathrm{V}$, southwest and central south China (Lu 2006)

\begin{tabular}{lcl}
\hline Content & $\begin{array}{l}\text { Ground river } \\
\text { (number) }\end{array}$ & $\begin{array}{l}\text { Discharge in dry } \\
\text { season }\left(10^{8} \mathrm{~m}^{3} / \mathrm{a}\right)\end{array}$ \\
\hline Regions & & \\
Yunnan & 148 & 39.02 \\
Guizhou & 1,130 & 71.35 \\
Sichuan & 895 & 63.96 \\
Chongqing & 201 & 28.68 \\
Guangxi & 435 & 191 \\
Hunan & 338 & 17.65 \\
Hubei & 211 & 14.85 \\
Total & 3,358 & 426.51 \\
\hline
\end{tabular}

Slopes account for much of the karst area, and the karst belongs to tropical and subtropical landscape. Karst types and underground karst rivers in the sloped mountain land 


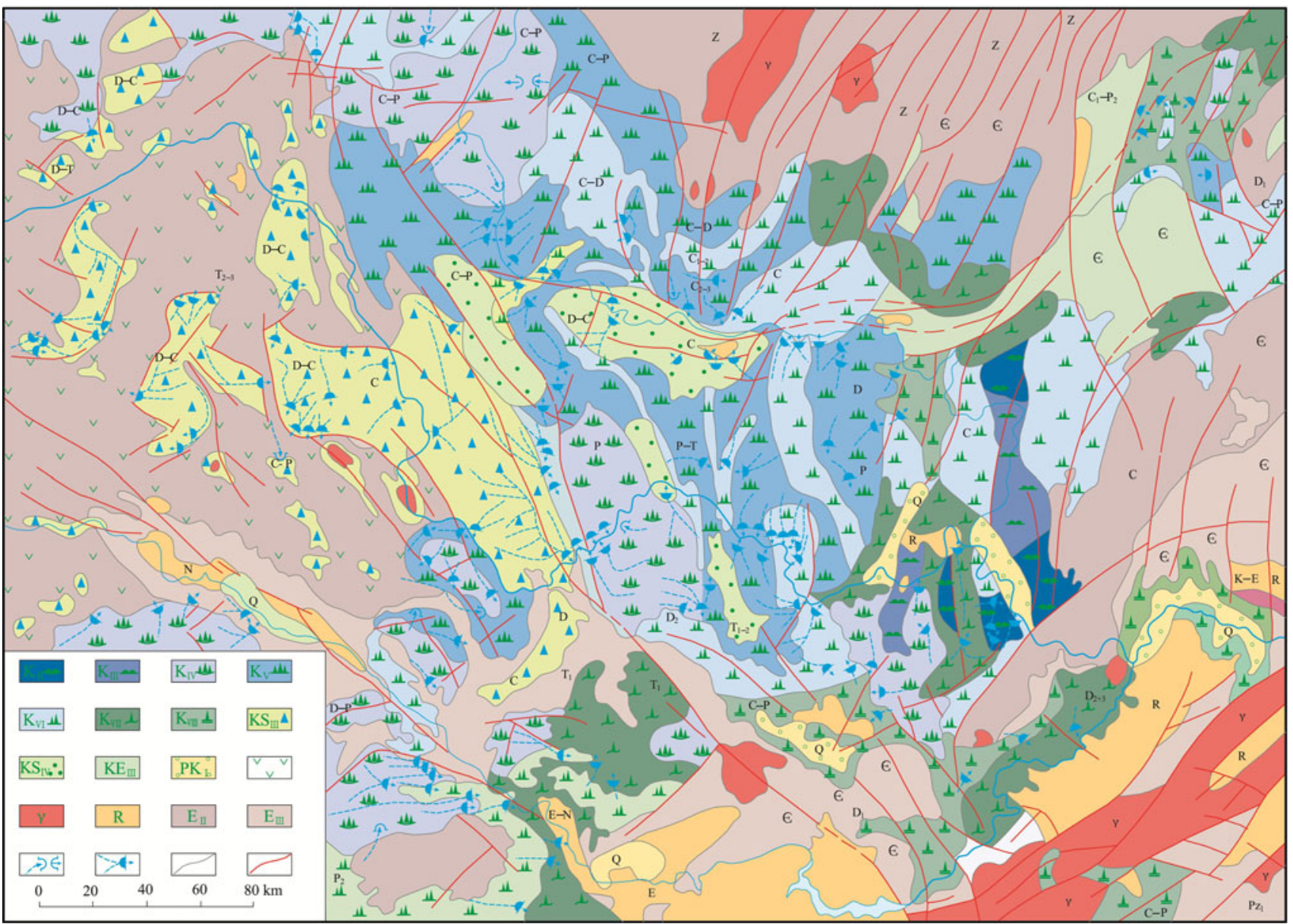

Fig. 3 Karst types and karst underground rivers in the sloped mountain lands between the Guangxi and Yunnan-Guizhou plateau. Bare karst areas: (1) open corrosion karst type (main corrosion karst type):1. Karst hill-depression type; 2. karst hills-valley type; 3. peak cluster-depression type; 4 . peak cluster-valley type; 5 . peak forestvalley type; 6 . isolated peak-hillside type; 7 . isolated peak-plain type (or peak forest-plain type); (2) restrictive dissolution karst type; 8. karst ridge-hillside type (fornix and the minor axis anticline region); 9. solution basin type; (3) erosion-corrosion type: 10. karst low mountain-valley type. Buried karst areas: (1) accumulation and subside karst type: 11. shallow accumulation and subside karst type; (2) structural depression karst type: 12. shallow structural depression karst type; Non-carbonate rocks exposed areas: 13. igneous rock; 14. Cenozoic red layer; 15. erosion middle mountain (non-carbonate rock areas); 16. erosion low mountain. Other features: 17. underground river entrance and exit; 18. underground river exit (part of the subsurface river); 19. limit of type; 20. main fault between Guangxi and Yunnan-Guizhou Plateau are illustrated in Fig. 3.

Major underground rivers characterize karst development in this southern area. Initial survey shows that there are 3,538 cave systems and discharge reaches $524 \times 10^{8} \mathrm{~m}^{3} / \mathrm{a}$ in drought periods.

For karst in region IV, northern China, bare and halfbare karst are mainly of tectonics-dissolution type and erosion-corrosion type, and mainly occur in the Taihang Mountains, and Yanshan and Yimeng Mountain areas. With relatively few caves, this area abounds in karst water in dissolved fracture channels, including hundreds of large karst springs. The biggest is the Niangziguan spring group in Shanxi province, whose average flow is $13 \mathrm{~m}^{3} / \mathrm{s}$ and peak flow is $16 \mathrm{~m}^{3} / \mathrm{s}$. The distribution of karst springs in northern China is shown in Fig. 4.

\section{Major problems of geological engineering effect in karst area}

Various engineering issues come to light in the process of the exploitation of resources and the construction of infrastructure in karst areas. This discussion focuses on two. 

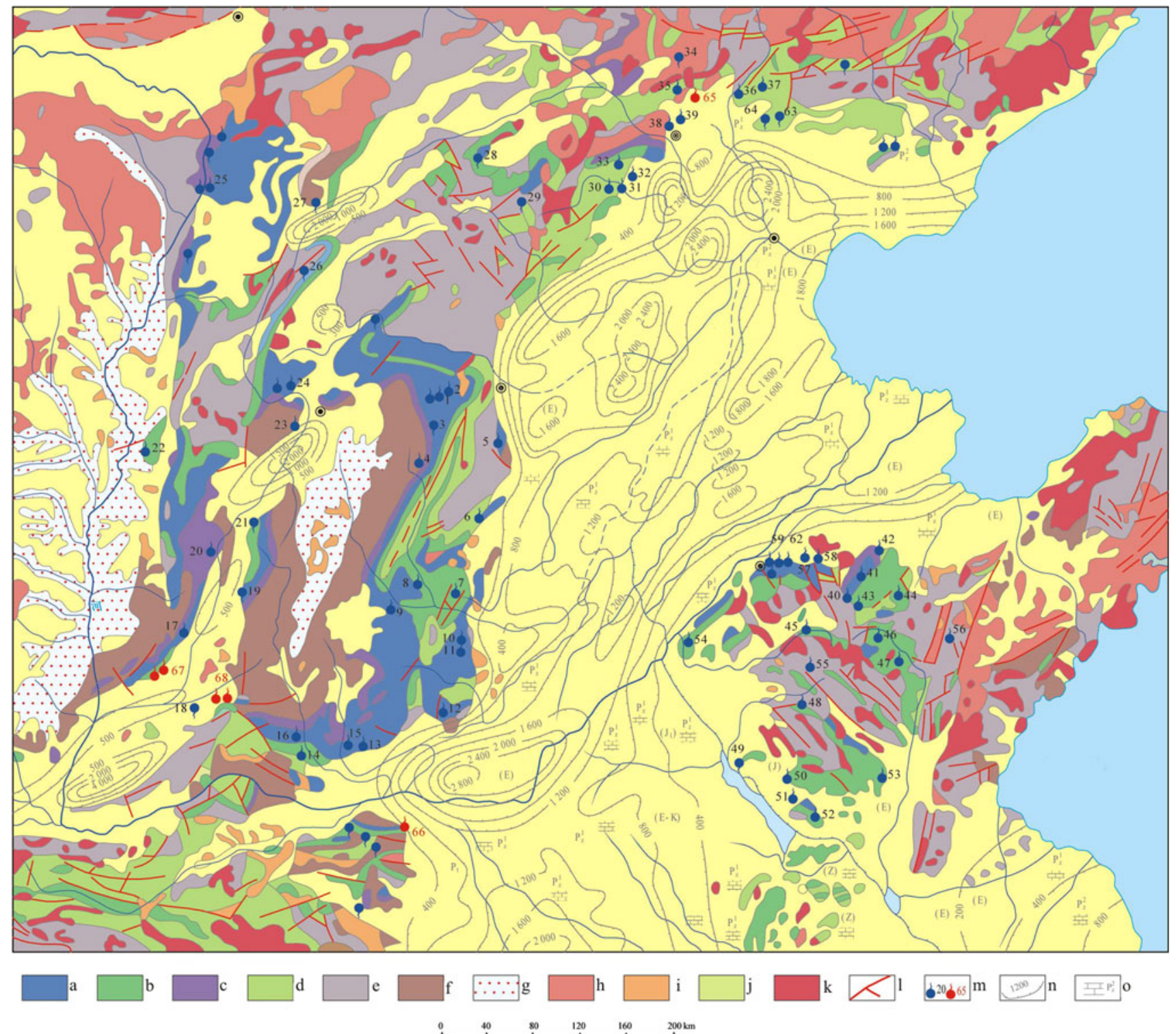

\section{h}

160

2001

Fig. 4 Map of major karst springs in northern China (Lu 1986). Bare karst areas: $a$ terrane of carbonate-based (Ordovician); $b$ carbonate rock groups with clastic rock (Cambrian-Ordovician); $c$ carbonate rock groups with clastic rock (Carboniferous); $d$ carbonate rock groups with clastic rock (Sinian); $e$ clasticor metamorphic rock groups with carbonate rock (Proterozoicus and Archeozoic). Other features: $k$ lava; $l$ fault; $m$ spring and number; $n$ isopach of Quaternary and Neogene, subside hollow direction; $o$ buried carbonate at the bottom of the Neogene and its stratigraphic descriptor. Spring names: 1 Niangziguan spring; 2 Weizhou Spring; 3 Donggubi Spring; 4 Shuishen Spring; 5 Shigu Spring; 6 Xingtaibai Spring; 7 Heilongdong Spring; 8 Dongfenghu Spring; 9 Xin'an Spring; 10 Zhenzhu Spring; 11 Xiaonanhai Spring; 12 Huixianbai Spring; 13 Jiulishan Spring; 14 Jiyuan Spring; 15 Sangu Spring; 16 Mashan Spring; 17 Longzici Spring; 18 Quwo Spring; 19 Guangshengsi Spring; 20 Guozhuang Spring; 21 Hongshan Spring; 22 Liulin Spring;
23 Jinci Spring; 24 Lancun Spring; 25 Tianqiao Spring; 26 Xiamaquan Spring; 27 Shentou Spring; 28 Shuishentang Spring; 29 Laiyuan Spring; 30 Gaozhuang Spring; 31 Ganchi Spring; 32 Heiniushui Spring; 33 Hebei Spring; 34 Shangshuigou Spring; 35 Huairouzhenzhu Spring; 36 Jinji Spring; 37 Huangcaowa Spring; 38 Heilongtan Spring; 39 Yuquanshan Spring; 40 Boshanshentou Spring; 41 Weitouhe Spring; 42 Fengshui Spring; 43 Longwan Spring; 44 Donglongwan Spring; 45 Guoniang Spring; 46 Nanshangu Spring; 47 Tongjing Spring; 48 Quanlin Spring; 49 Yuanyuan Spring; 50 Jing Spring; 51 Yangzhuang Spring; 52 Shili Spring; 53 Linyi Spring; 54 Shuyuan Spring; 55 Gongli Spring; 56 Miaogou Spring; 57 Dongmawan Spring; 58 Ximawan Spring; 59 Baotu Spring; 60 Heihu Spring; 61 Zhenzhu Spring; 62 Wulongtan Spring; 63 Gongleting Spring; 64 Jixiandong Spring; 65 Xiaotangshan hotspring; 66 Mixian hotspring; 67 Gudui hotspring; 68 Haitou hotspring 

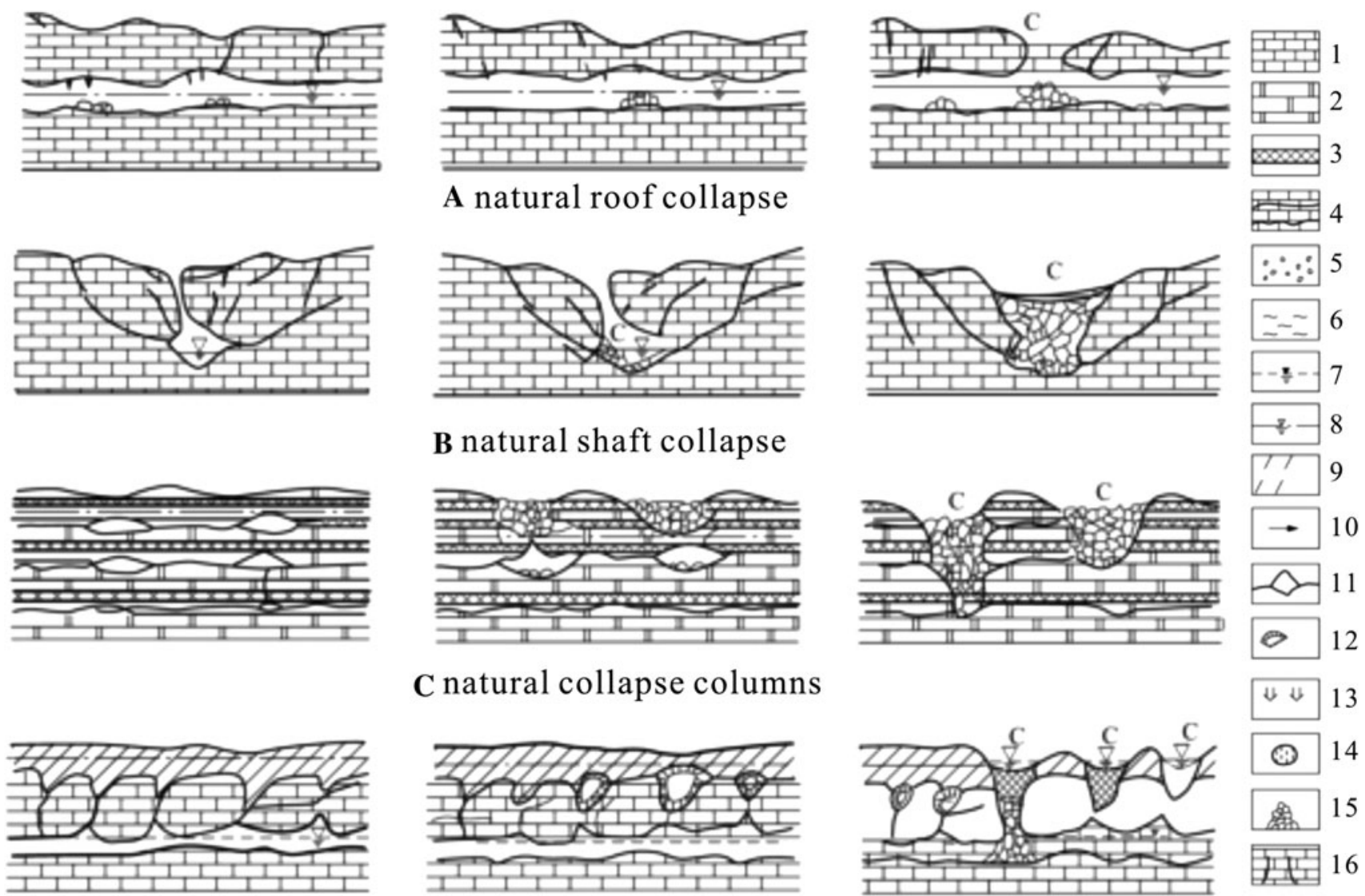

\section{C natural collapse columns}
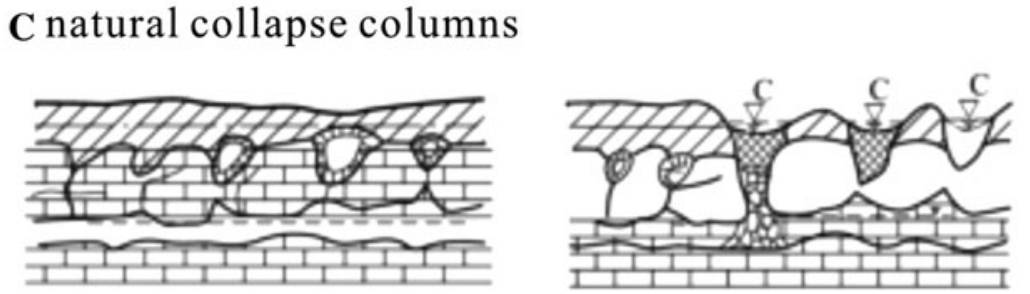

D natural ground cave and soil cave collapse of the overlaying soil

Fig. 5 Illustration diagram of causes for natural karst collapses (Lu 2003). 1 limestone; 2 dolomite; 3 plaster; 4 clay; 5 gravel; 6 silt; 7 surface water level; 8 groundwater level; 9 water potential line;

\section{Karst collapse}

In carbonate rock areas, construction of water conservation and hydropower structures or exploitation of underground water and mineral resources induces karst collapses: this phenomenon is inevitable in karst development. Meanwhile, the influence of natural conditions, such as earthquakes, major floods, and drought, also accelerates and exacerbates karst collapses. Some of the largest karst collapses are called Tiankeng (natural pits) (Zhu et al. 2003).

The formation mechanism of natural karst is illustrated in Fig. 5 (Lu 2003).

In sulfate rock (plaster) areas, karst collapse columns are widely seen. This is a special collapse of natural karst, and is also known as vertical traveling structure (VTS). Types of karst collapse columns in Northern China, are summarized in Fig. 6 (Lu and Feng'e 2007).
10 flow direction; 11 cave; 12 soil cave; 13 seepage flow; 14 clay filling; 15 collapse block; 16 karst collapse masses

\section{Karst water invasion}

Within mining pits and tunnels in karst regions, groundwater invasion is frequently accompanied by significant soil-rock materials, which create more harm. The maximum quantity of karst water invading mining pits or tunnels has reached $10 \mathrm{~m}^{3} / \mathrm{s}$.

For example, in construction of high-speed railway and water conservation structures, tunnels longer than $10 \mathrm{~km}$ have been excavated. But the damage, by karst water-soil invasion has made the engineering much more difficult (Fig. 7).

\section{Main natural hazard linkages in karst regions of China}

In karst regions, many environmental problems are directly linked to some natural hazard. For example, these include 
Fig. 6 Comprehensive schematic drawing of karst collapse columns in northern China Bare karst collapse columns: a Yangquan, Shangxi province; b Niangziguan, Shanxi province; c No. 5 mine Jingxing, Hebei province; Buried karst collapse columns: d, e No. 9 mine Fengfeng, Henan province; f Jingxing mining, Hebei province; $\mathbf{g}$ No. 1 mine Jingxing, Hebei province 1 carbonate rock; 2 carbonate and breccia rock; 3 Sandstone and shale; 4 coal seam and Clastic rocks; 5 fault; 6 karst collapse columns; 7 conjectural boundary of karst collapse columns; 8 paleokarst surface between $\mathrm{O}_{2} \mathrm{f}$ and $\mathrm{C}_{2}$ ( $\mathrm{Lu}$ and Feng'e 2007)
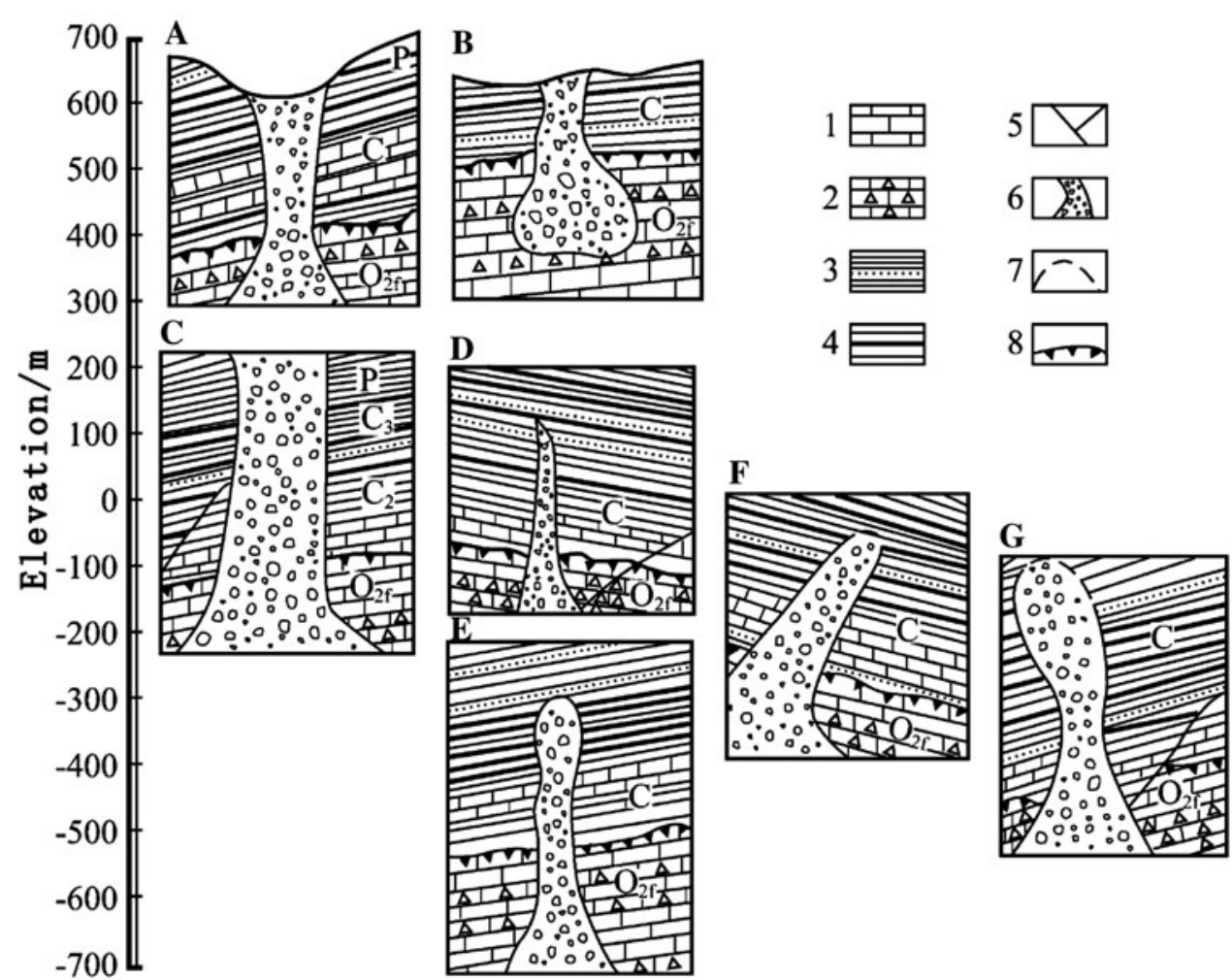

A

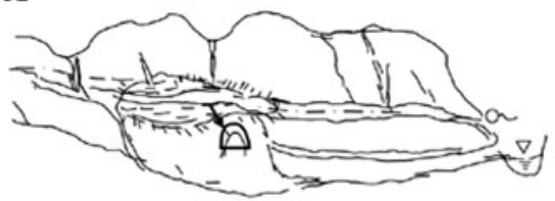

C

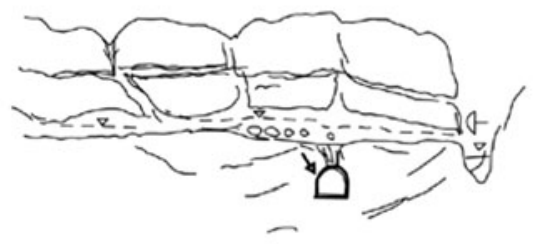

E

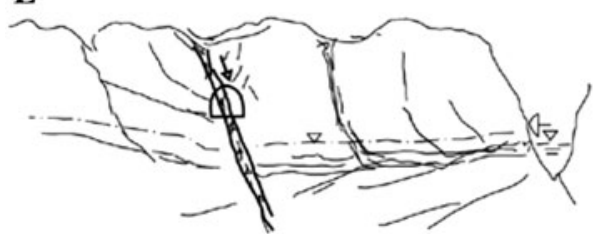

B

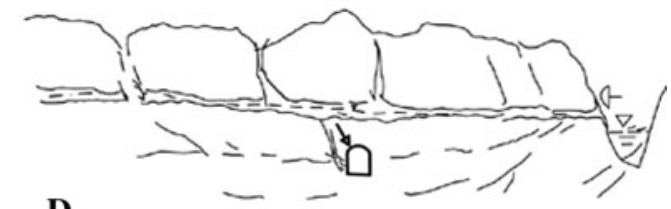

D

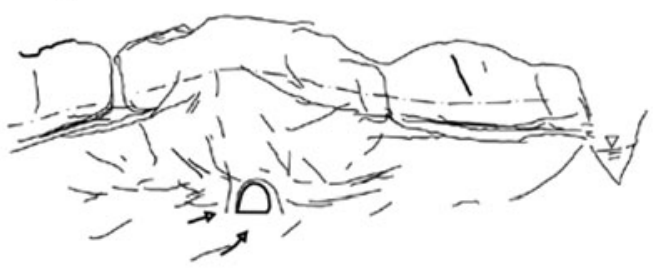

F

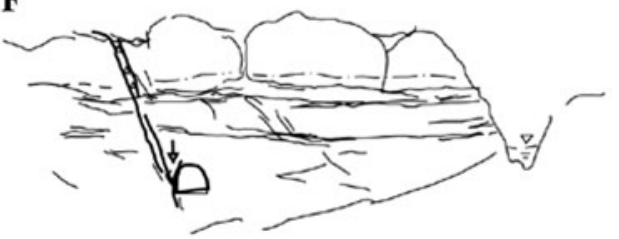

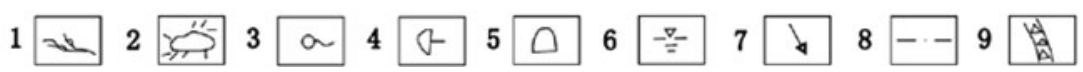

the relation between climatic hazard (storm) and landslide, debris flow, and karst collapses, the linkage between earthquakes and landslides, debris flows, and karst collapse.
The Wenchuan earthquake in the 12 May 2008 (magnitude 8.0), caused a series of landslides, debris flows, and collapses throughout the karst regions. 


\section{Conclusion}

Karst environmental conditions usually include both resource factors and hazard factors. For the exploitation of different resources in karst regions, it is very important to avoid geohazards such as karst collapses, landslides, and debris flows as well as causing karst water invasion. Otherwise, according to the local hazard conditions, treatment can be implemented for decreasing the natural hazard and reducing potential harm.

Open Access This article is distributed under the terms of the Creative Commons Attribution License which permits any use, distribution, and reproduction in any medium, provided the original author(s) and the source are credited.

\section{References}

Lu YR (1986) Karst in China-landscape type rules [China]. Geological publishing house, Beijing
Lu YR (1999) Research on the evolutions of karst hydrogeological environments and their engineering impacts [China]. Science press, Beijing

Lu YR (2003) Geo-ecology and sustainable development. Nanjing [China]. Hohai university press, Jun

Lu YR (2007) Karst water resources and geo-ecology in typical regions of China. Environ Geol 51(5):695-699

Lu YR (2012) Karst in China-the world of special peaks and wonderful caves. High Education Press, Beijing

Lu YR, Zhang FE (2007) Sulphate rock karst and sulphate-carbonate rocks compound karst [China]. High Education Press, Beijing

Lu YR, Jie XY, Zang SL et al (1973) The development of karst in China and some of its hydrogeological and engineering geological conditions. Acta Geologica Sinica 1:121-136

Lu YR, Zhang FE, Liu CL, Tong GB et al (2006) Groundwater systems and eco-hydrological features in the main karst regions of China. Acta Geologica Sinica 80(5):743-753

Zhu XW, Huang BJ, Zhu DH et al (2003) Dashiweitiankeng group, Leye, Guangxi-Discoveries Exploration and Scientific Research. Guangxi science and technology press, Nanning 